International Review of Social History 44 (1999), Supplement, pp. 123-147

(C) 1999 Internationaal Instituut voor Sociale Geschiedenis

\title{
From Muscles to Nerves: Gender, "Race" and the Body at Work in France 1919-1939*
}

\section{LAURA LEVINE Frader}

In the years before and immediately after World War I, gendered and racialized bodies at work became the focus of debate and discussion in France amongst an informal alliance of engineers, doctors, scientists, employers, workers, and the state. 'Seduced by the promise of "modernity", and the seemingly endless possibilities of science and mechanization, the state attempted to modernize public services and employers sought new ways to discipline labor for greater productivity. Both mobilized rationalization Taylorism and work science - in the service of greater efficiency and in an effort to identify the allegedly "natural" qualities that made gendered and racialized workers suitable for certain kinds of jobs and would exclude them from others. ${ }^{2}$ A not insignificant dimension of this project lay in how

* The author thanks Nancy Green for suggesting the title of this essay, and Eileen Boris, Antoinette Burton, James Cronin, Rayna Rapp, and Eve Rosenhaft for comments on earlier drafts.

I. Gendered bodies were already the site of considerable debate throughout the nineteenth century in discussions about the right to work, social and family policies, the qualifications of citizenship and the problem of male military preparedness. See, for example, Robert A. Nye, Crime, Madness, and Politics in Modern France: the Medical Concept of National Decline (Princeton, NJ, 1984); George Mosse, Nationalism and Sexuality: Respectability and Abnormal Sexuality in Modern Europe (New York, 1985); and Anson Rabinbach, The Human Motor: Energy, Fatigue, and the Origins of Modernity (New York, 1990), pp. 224-228. Rabinbach's work is the most extensive study of work science in English, although the book is not designed to focus on the gender or race dimensions of work science. See also, Mary Lynn Stewart, Women, Work, and the French State (Montreal, I991); L.R. Villermé, Tableau de L'Etat physique et moral des ouvriers employés dans les manufactures de coton, de laine, et de soie (Paris, 1971); Leora Auslander and Michelle Zancarini-Fournel (eds), Différence des sexes et protection sociale. xix'-xx' siècles (St Denis, 1995); Susan Pedersen, Family, Dependence, and the Origins of the Welfare State: Britain and France 1914-1945 (Cambridge, 1993) and Seth Koven and Sonya Michel (eds), Mothers of A New World (New York and London, 1995); Rachel Fuchs, Eleanor Accampo et al., Family, the State, and Welfare in Modern France (Baltimore, MD, 1996); Kathleen Canning, Languages of Gender and Labor: Female Factory Work in Germany, 1850-1914 (Ithaca, NY, 1996); Laura Lee Downs, Manufacturing Inequality (Ithaca, NY, 1995); and Laura Levine Frader, "Social Citizens Without Citizenship: Working-Class Women and Social Policy in Interwar France", Social Politics, 3 (1996), pp. III-135. On the the way in which this collaboration constructed "a new image of class relationships", see Charles Maier, "Between Taylorism and Technocracy", Journal of Contemporary History, 5 (1970), p. 29.

2. For examples of the naturalizing discourses addressed to the "inherent qualities" of women, see, for example, Anne Phillips and Barbara Taylor, "Sex and Skill: Notes Towards a Feminist Economics”, Feminist Review, 6 (1980), pp. 79-88; Harriet Bradley, Men's Work, Women's Work (Minneapolis, MN, 1989); Helen Harden Chenut, "The Gendering of Skill as Historical Process: the Case of French Knitters in Industrial Troyes, 1880-1939", in Laura L. Frader and Sonya O. Rose (eds), Gender and Class in Modern Europe (Ithaca, NY, 1996), pp. 77-107; and Downs, Manufacturing Inequality. 
French work scientists began to envision the potential uses of gendered French and colonial labor. The development of the French North-African and Indochinese colonial empires around the turn of the century heightened attention to racialized difference. World War I had opened the opportunity to use racialized colonial bodies, both on the military front and in the factory. ${ }^{3}$ Thinking about race and gender characteristics continued to influence work science and its applications in the 1920s and 1930s. Work scientists' experiments to ascertain the physical endurance of colonial male workers and white workers underscored the durability of gender meanings in dealing with white French workers and the instability of those meanings in assessing the abilities of workers of color.

This paper shows how gendered and racialized working-class bodies became the sites of "modernization" after the war and focuses on the science of work as one aspect of the rationalizing impulse in interwar France. ${ }^{4}$ Operating from the assumption that gender, race, and class, are mutually constitutive, rather than separate and parallel categories of difference, the paper investigates how race and gender both complicated the notion of "class" as well as inflecting each others' meanings: gender complicated the meanings of race and vice versa, illustrating the instability of meanings often assumed to be fixed.' However, the particular meanings of "race" and common uses of racial vocabulary in France between the wars may not have been exactly the same as the meanings of this term in other national contexts. This particularity introduces another level of complexiry into discussions of how race operated as a marker of difference. Even though "whiteness" and "blackness" may have functioned as categories within the context of French anthropology, it is not clear how generalized they had

3. See B. Nogaro and Lucien Weil, La main d'oeuvre etrangère et coloniale pendant la guerre (New Haven, CT and Paris, 1926); Tyler Stovall, "Color-blind France? Colonial Workers During the First World War", Race and Class, 35 (1993), pp. 35-55 and Stovall, "The Color Line Behind the Lines: Racial Violence in France During the Great War", American Historical Review, 103 (1998), Pp. 737-769, which analyses the different responses of the French to North African immigrant labor versus European immigrant labor. Stovall argues that the war lessened tensions between the French and European immigrants whereas it heightened hostility towards colonial workers of color. On immigrant workers, see Gary S. Cross, Immigrant Workers in Industrial France. The Making of a New Working Class (Philadelphia, PA, 1983) and John Horne, "Immigrant Workers in France During World War I", French Historical Studies, 24 (1985), Pp. 57-88, and Horne, Labour at War: France and Britain 1914-1918 (Oxford, 1991).

4. See Rabinbach's discussion of cultural and social modernity with reference to the science of work in The Human Motor.

5. On the mutually constitutive character of these categories, see introduction in Sandra Harding, The "Racial" Economy of Science: Towards A Democratic Future (Bloomington, IN, 1993). As Harding writes, "[...] it is clear that "race" and gender, racism and sexism, construct and maintain each other [...]. Class and gender policies have constructed and maintained racial hierarchies just as race policies have done for class and gender hierarchies" ( p. II). See also Carole Turbin, Laura L. Frader, Sonya O. Rose and Evelyn Nakano Glenn, "A Roundrable on Gender, Race, Class, Culture and Politics: Where Do We Go From Here?", Social Science History, 22 (1998), pp. I-45. 
become in the popular vocabulary of racial identification in France. In any case, whiteness was never merely about color, alone. The French notion of race was strongly linked to membership in the national community - to Frenchness or non-Frenchness. ${ }^{6}$ As I shall suggest below, "French" was coded as white even before "whiteness" entered the popular lexicon in the way it had in, say, the United States, where the consciousness of race was not only the shadow presence of an overseas colonial empire, but where the language of racial difference and the social exclusions of race had long been part of the vocabulary and social fabric of everyday life.

I argue first, that in spite of their claims to "science" - a term that signified neutrality and objectivity - the social and medical investigators who practiced and promoted the science of work in the period from 1900 to 1939, hardly treated the body as a neutral biological entity. As Sandra Harding has observed, science itself is constituted by historical and cultural meanings and practices that are never absent from its cognitive core. For centuries, science has been complicitous in perpetuating racist and gendered as well as Eurocentric assumptions and beliefs. ${ }^{7}$ As the object of work scientists' investigations into fatigue and endurance, the working body could never be separated from its gendered, racialized, or cultural meanings and those meanings permeated the investigations of work science. ${ }^{8}$ Moreover, work science and employer practices revealed the instability of the meanings of "race" - through their attention to bodies identified as explicitly racialized and through their silences on race. My task here is to look at how employers and the state deployed those meanings in analyzing and appropriating the bodies of workers. I hypothesize that despite its silence on race, racialized

6. I am grateful to Rayna Rapp and to Ann Laura Stoler for conversations on this subject. See Stoler, "Racial Histories and Regimes of Truth", Political Power and Social Theory, II (1977), pp. 183-206. See also Stoler and Frederick Cooper, "Between Metropole and Colony", in Cooper and Stoler (eds), Tensions of Empire: Colonial Cultures in a Bourgeois World (Berkeley, CA, 1997). As Stoler and Cooper write, citing George Stocking and others, "the concepts of culture and race have long served to buttress one another in crucial ways [...] [racism] has long depended on hierarchies of civility, on cultural distinctions of breeding, character, and psychological disposition, on the relationship between the hidden essence of race and what were claimed to be its visual markers" (p. 34). On the links between notions of racial difference and the nation, see Kenan Malik, The Meaning of Race. Race, History, and Culture in Western Society (New York, 1996), pp. 128-I48; Herman Lebovics, True France: The Wars Over Cultural Identity 1900-1945 (Ithaca, NY, 1992). On the cultural distinctions of "civility" and their links to concepts of the nation, and to class, see Norbert Elias, The Civilizing Process (Oxford and Cambridge, 1994), especially part I, ch. 2 .

7. See Harding, "Racial" Economy of Science. As Harding points out, science itself is laden with conflicting tendencies: regressive collaboration with racist and eurocentric beliefs on the one hand; and on the other hand, the progressive effects of "scientific procedures that have proved effective in identfying racist and imperialist tendencies in the sciences [...]", (p. I4).

8. In the words of Roy Porter, "the body must be regarded as mediated through cultural sign systems". See Porter, "History of the Body" in Peter Burke (ed.), New Perspectives on Historical Writing (University Park, PA, 1992), p. 215. 
categories may have been marginally more important to the state (than to private sector employers) in establishing the quality and efficiency of public services such as the telephone and telegraph service. Secondly, although French industrialists and the state adopted neither Taylorism or work science wholesale, the rationalizing impulse of Taylor as well as that of work science could be found not only in industrial work, but also in the organization of public sector service work, where ideas about gender and race characteristics influenced employment policy.

\section{RATIONALIZING THE WORKING BODY}

In late nineteenth-and early twentieth-century France, Taylorism and work science developed as two competing approaches to rendering workers more productive and efficient.9 Taylorism, imported into France shortly after Taylor's publication of the Principles of Scientific Management and other works in the United States, focused on managers' capacity to organize work effectively and efficiently by measuring the motions of the body through time and regulating the body according to plan. ${ }^{10}$ In spite of dramatic protests against the implementation of time and motion studies on the shop floor, notably at the Renault automobile works before the war, some workers (notably in the General Confederation of Labor, CGT) promoted Taylorism under the assumption that better organization of the labor

9. On these two approaches and their policy consequences in France and Britain, see Gary Cross, A Quest for Time: The Reduction of Work in Britain and France, 1840-1914 (Berkeley, CA, 1989), chapter 5. See Rabinbach, The Human Motor, which examines the important German (as well as French) contributions of this movement.

Io. Taylor's first work published in France in 1907, Etude sur l'organisation du Travail dans les Usines was published by the Revue de la Métallurgie; subsequent works were published in French within a year of their appearance in the United States. There is a voluminous literature on Taylorism apart from Taylor's own published work. For a sampling of the literature on the reception of Taylorism in France, see Patrick Fridenson, "Un Tournant Taylorien de la Société française (1904-1918)" in Annales ESC, 5 (1987),pp. 1031-1060; Yves Cohen, "Ernest Mattern chez Peugeot (1906-1918) ou comment peut-on être taylorien?", in Maurice de Montmollin and Olivier Pastré (eds), Le taylorisme (Paris, 1984); Aimée Moutet, Les logiques de l'entreprise (Paris, 1997); O. Christin, "Les Enjeux de la rationalisation industrieile (190I-1929)", Mémoire de Maîtrise, Université de Paris I, 1982. See also Maier, "Between Taylorism and Technocracy", on the cultural and political appeal of Taylorism; and Rabinbach, "The European Science of Work: the Economy of the Body at the End of the Nineteenth Century", in Stephen Laurence Kaplan and Cynthia J. Koepp (eds), Work in France. Representations, Meaning, Organization, and Practice (Ithaca, NY, 1986), p. 475, n.I. See also Cross, "Redefining Workers' Control: Rationalization, Labor Time, and Union Politics in France, 1900-1928", in James E. Cronin and Carmen Sirianni (eds), Work, Community, and Power: The Experience of Labor in Europe and America, rooo-1925 (Philadelphia, PA, 1983), pp. 143-172; Aiméc Moutet, "Patrons du Progrès ou Patrons de Combat? La politique de rationalisation de l'industrie française au lendemain de la Première Guerre mondiale, in Lion Murard and Patrick Zylberman (eds), Le Soldat du Travail. Guerre, fascisme, et taylorisme (Paris, 1978), pp. 449-489. See also Georges Ribeill "Les Organisations du mouvement ouvrier en France face à la rationalisation (1926-1932)", in de Montmollin and Pastré, Le taylorisme. 
process would make work easier and ultimately provide workers with more leisure time. ${ }^{\text {II }}$ Taylor's model of scientific management was not simply about measuring the body's effective and efficient performance of tasks; it also involved a new model of managerial authority aimed at the reorganization of the entire labor process through a more refined and intensified division of labor. In its application, gender often played a fundamental role where the body was the site of new forms of labor regulation. Indeed, it may be nearly impossible to speak about Taylorism without speaking at the same time of gender and racialized divisions of labor. ${ }^{12}$ The same was true of work science.

At the very moment that Taylorist rationalization found an audience among French industrialists and engineers, important critiques of Taylors' methods emerged from a small but growing group of psychologists and doctors who focused directly on the human body as the site of investigation and regulation. This was not a new development historically; from the late eighteenth and early nineteenth centuries the economic rationality of capitalist work discipline involved regulating the bodies of workers to conform to the pace of industrial time and the rhythm of the machine. ${ }^{13}$ But the particular focus on the body of the worker intensified at the end of the nineteenth century and in the years around World War I. Moreover, as Anson Rabinbach has argued, "the science of labor was certainly not, like Taylorism, simply an ideology of management [...]. It was a struggle over energy and fatigue rather than time and money. ${ }^{{ }^{14}}$

Work scientists like Jean-Marie Lahy recognized the importance of the scientific organization of labor, especially given the loss of labor power due to wartime mortality and the employment of women in jobs formerly coded male." However, Lahy argued that Taylor's focus on productivity had led to ignoring the wellbeing of the worker. Taylor's error was that he had assimilated human beings to machines and omitted the "human factor", especially the problem of fatigue. Lahy attempted to determine the fit between workers and their jobs by analysing their psycho-physiological signs of professional inclination - work that would ultimately lead to professional aptitude testing. Studying endurance and fatigue would allow workers to reduce wasted motions, use their energy more effectively, and become more

Ir. Cross, "Redefining Workers' Control".

12. Hirata, "Division internationale du travail et taylorisme: Brésil, France, et Japon", in de Montmollin and Pastré, Le taylorisme.

13. Edward P. Thompson, "Time, Work Discipline and Industrial Capitalism", Past and Present, 38 (1969), pp. 56-97.

I4. Rabinbach, "The European Science of Work", p. 506, n. III. The first stage "represented the creation of a disciplined workforce; the second was characterized by the struggle over the duration and value of labor time", $i$ ibid.

15. Jean-Marie Lahy, Le Système Taylor et la Physiologie du Travail Professionnel (Paris, I921), Préface, p.v. On Lahy's critique of Taylor, see also Rabinbach, The Human Motor, pp. 250-252. 
productive. ${ }^{16}$ In their laboratory experiments, conducted largely on white French males, Lahy's fellow work scientists Etienne-Jules Marey and Charles Frémont, Auguste Chauveau, Jules Amar, and Armand Imbert applied the principles of general mechanics to the human machine, measuring carbon dioxide-oxygen exchange, muscular effort, and charting the body's motions in different occupations ranging from mechanics to public speaking. ${ }^{17}$ To this work on the body, in the first decade of the twentieth century, psychotechnicans Alfred Binet, Charles Henry, and Edouard Toulouse added the notion that given the seeming inevitablity of overwork and fatigue in modern labor, experimental and physiological psychologists could help industry effectively use its human capital by developing methods of selection. Their measures of professional aptitude and aptitude tests led to the practices of vocational guidance after World War ${ }^{18}{ }^{18}$ Finally, if these work scientists and their medical and psychologist allies constituted a minority in France, by the eve of World War I, work scientists had established a broad international network of journals and conferences. Although historians have tended to treat the "science of work" that emerged in this period as gender and race-neutral, differently sexed and racialized bodies most definitely entered the calculus of work science. ${ }^{19}$

\section{GENDERED BODIES AT WORK DURING WORLD WAR I}

In so far as all bodies are sexed, gendered, and racialized, it was impossible for either studies of the body or the applications of work science not to

16. See Lahy, Le Systeme Taylor, pp. 156-157. Taylorism and work science both shared productivist goals; Rabinbach, The Human Motor, p. 253.

17. As Rabinbach points out, the science of labor had to take account of changes in the labor process going on outside the laboratories in which it was first conceived. "Concern with fatigue, time, and motion, reflected deep social changes in the nature of the factory and the emergence of a workforce that no longer had to be subjected to the moral economy of industrial discipline outside the workplace. Instead, workers had to be taught to internalize the tegularity imposed by machine technology and adapt to newly intensified work norms", Rabinbach, "European Science of Work", p. 507. See also Ribeill, "Les débuts de l'ergonomie en France à la veille de la Première Guerre mondiale", Le Mouvement Social, II3 (1980), pp. 3-36; and Claudine Fontanon and André Grelon (eds), Les Professeurs du Conservatoire national des arts et métiers. Dictionnaire biographique, 1794-1955, 2 vols (Paris, 1994). It is quite possible that in measuring the efforts of the white male body these scientists were also struggling with their own definitions of masculinity. I am grateful to Antoinette Burton for this suggestion.

I8. Ribeill, "Les débuts de l'ergonomie en France", p. 2r.

I9. The attention to race in the works of work science experts such as Jules Amar was partly based on early anthropological attempts to classify and evaluate the capacities of humans according to anthropometrics. See Jules Amar, Le Moteur humain et les bases scientifiques du travail professionnel, 2nd edition (Paris, 1923), p. I51. On race in the science of work, see also Elisa Camiscioli, "Labor Power and the Racial Economy: the Selection of Foreign Workers in France in the Late Third Republic", paper presented to the conference, "Blurring the Boundaries: Politics and Culture in the French Third Republic", University of Michigan, Ann Arbor, MI, 1997. 
incorporate ideas about perceived or socially-constructed gender or racialized difference. War provided one arena for the application of work science with distinctly gendered implications. In the $1880 \mathrm{os}$, in the context of the revanchiste response to the French defeat during the Franco-Prussian war, work scientists had examined the marching patterns of military men, and promoted gymnastics training for white French schoolboys in the interest of military preparedness. ${ }^{20}$ Scientists then linked improving the health and stamina of the white male body to national strength and proposed the rational application of physiology to physical education and diet. ${ }^{2 I}$ These ideas also inspired Jean-Marie Lahy's subsequent tests of machine gunners' reaction times and fatigue in order to understand the "cold-bloodedness" of soldiers - their ability to withstand the psychological as well as the physical duress of war. ${ }^{22}$

As historians like Laura Downs and Patrick Friedenson have shown, World War I proved to be an important testing ground for experimentation with Taylorism, particularly in integrating women into jobs formerly designated as "men's jobs" in the metalworking and defense industries. It was also an important moment for applying the science of work. ${ }^{23}$ As Downs has shown, the process of fragmenting the labor process into semiskilled and unskilled work enabled employers to hire women as a separate category of worker to staff the new positions. Women's bodies became a special focus of interest. Employers singled out women's supposedly inherent dexterity and their alleged ability to withstand monotonous, routinized labor, and spoke of their bodies as almost naturally attuned to the movements of the machine in order to justify employing women on certain processes in metalworking. ${ }^{24}$ Work scientists also collaborated with employers and the state during the war in attempting to reconcile the strategic objectives of stimulating war production with the occasionally disturbing incongruity of womens' work in jobs formerly gendered male. Marcel Frois' investigations for the

20. The law of 27 January 1880 required gymnastics training for boys in lycees; Rabinbach, The Human Motor, p. 224. According to Amar, the physiologist Mosso wrote that "the catastrophe of Sedan will go down in history as the victory of German legs"; Amar, Le Moteur bumain, p. 673. 21. Rabinbach, "The European Science of Work", p. 492; The Human Motor, pp. 130-131, 224227, 265-270. See also Alain Ehrenberg, Le corps militaire: politique et pédagogie en démocratie (Paris, 1983).

22. Rabinbach, The Human Motor, p. 265. During the war, work scientists investigated the possibilities of rehabilitating wounded soldiers. Amar in particular worked on the re-education of wounded men and on the development of prostheses that would enable war cripples to return to work. His work concerned exclusively white French soldiers. See Amar, The Physiology of Industrial Organization and the Re-Employment of the Disabled (New York, 1919), pp. 227-358. See also Hugues Monod, "Jules Amar", in Fontanon and Grelon, Les Professeurs du Conservatoire national, vol. 2, pp. 102-103.

23. See Downs, Manufacturing Inequality; Annie Fourcaut, Femmes à l'usine: ouvrières et surintendantes dans les enterprises françaises de l'entre-deux-guerres (Paris, 1982); Simone Weil, La condition ouvrière (Paris, 1951).

24. Downs, Manufacturing Inequality, pp. $83-84$. 
French Ministry of Armaments and War Manufactures of the health and working conditions of women in the newly Taylorized defense industry in 1916 and 1917 demonstrated how investigators used the scientific study of morion and fatigue to assess the impact of work on the white female body. Frois concluded that although the bodies of women disqualified them for work necessitating muscular force or sustained physical effort, their great motor sensibility (grande sensibilité motrice) meant that industry could effectively utilize their distinctive ability to perform rapid and precise movements. As a result, Frois encouraged employers to modify machinery and production processes in order to hire women. ${ }^{25}$

In addition to the naturalization of the link between women's bodies and the machines on which they worked, the process of rationalization during the war also included the establishment of industrial welfare policies designed to regulate the body of the white female worker, with special attention to her health and hygiene, pregnancy and domestic life. In the silence on race in the discussions of labor practices and policies, one detects the pervasive assumption that women were French and therefore white. ${ }^{26}$ Employers operated on the premise that healthy women would be the most productive workers, but they were also specifically interested in protecting the health and hygiene of the "mothers of the race". Women's wartime munitions work was not to interfere with the reproductive capacities of white French women. ${ }^{27}$ Partly in response to the devastating mortality of

25. Ibid., p. 84; Marcel Frois, La Santé et le travail des Femmes Pendant la Guerre (Paris and New Haven, CT, 1926), p. 62. Frois' concerns about the white female working body were echoed by British investigations into munitions workers for the Health of Munitions Workers' Committee in 1917 and 1918. See Cross, $A$ Quest for Time, p. 117. Not all work scientists agreed about the employability of white women in "male" jobs. Jules Amar reviewed differences in the cardiograms of French men and women responding to the sound of the fall of a two kilogram weight. He found that the cardiograms showed strong changes in the women tested, but a negligable changes or none at all in the men - the difference attributable to women's sensation of fear and powerlessness and their greater emotional susceptibility; Mathilde Dubesset, Françoise Thébaud and Catherine Vincent, "Les munitionettes de la Seine", in Patrick Fridenson (ed.), I9I4-I9I8: l'autre front (Cahiers du Mouvement Social, 2) (Paris, 1977), pp. 189-219, 196, fn. 34. Amar's conclusions were bolstered by anthropometric data from the 1860 and 1870 os that demonstrated women's inferiority to men in measures of height, weight, lung displacement (capacite vitale), thoracic volume, and muscular strength. Amar argued that in general "the shape of the body [...] provides a guide for the workers' choice of one form of work over another [...] normally, men are organized and constructed to work in a certain way because this is the way their work is most economical"; Amar, Le Moteur humain, pp. 148 and 148-178. Amar argued that as a general rule physical proportions determined professional aptitides. See also pp. 323-324 for Amar's attempt to classify men according to morphology or the "architecture of their bodies". Thus, he argued that "in the vast majority of work requiring great effort and sustained attention [une attention puissante], there is no place for women workers. They are more appropriate for office occupations". Ibid., p. 606. 26. Immigrant colonial workers and workers of color during the war were overwhelmingly men. See below.

27. As Downs notes, the original intentions of the founders of the system, organized around republican feminist Cécile Brunschvicg, were to promote wage parity for women with men, over- 
World War I, and French policy geared to improving population growth as a form of social and economic recovery, the women factory superintendents charged with overseeing the implementation of industrial welfare expanded their activities in the 1920 s and 1930s and spent more time helping women reconcile their factory labor with maternity. In some of the automobile factories, they also supervised the establishment of home economics schools, sewing schools, and sports teams, all designed to help women maintain healthy bodies. ${ }^{28}$ Thus the application of scientific management had a gender-specific dimension. The use of explicitly racialized colonial male labor during the war, however, complicated the attibution of gender characteristics to workers.

\section{GENDER AND COLONIAL LABOR}

Racialized male colonial labor was also employed in munitions work, occasionally side by side with white French women, and as Tyler Stovall has shown, French authorities regarded the intermingling of genders and races on the job with real concern. Such intermixing threatened to weaken the color boundaries that normally separated differently gendered and raced workers. ${ }^{29}$ Despite the fact that the category "race" only entered work scientists' lexicon when they investigated male colonial workers, their observations of colonial workers threw into relief the ways that the white working-class European body was also a racialized body and simultaneously illustrated the instability of the category gender when inflected by race. ${ }^{30} \mathrm{It}$ also illustrated how class and race intersected in the minds of work scientists. $^{31}$

During the war, the French government coordinated the hiring of some 222,000 colonial and foreign men from Tunisia, Morocco, Algeria, Indochina, Madagascar, and China on limited-term contracts of up to a year (with the provision that they return to their countries of origin at the expiration of the contract); colonial women did not migrate to France as a form of reserve army of labor. The vast majority of men were employed in munitions work. Work scientists paid close attention to these men's resistance to fatigue, and the experience revealed assumptions about how

see their working conditions, and ultimately to protect "women's maternal capacity through careful administration of the factory's welfare and maternal services"; Downs, Manufacturing Inequality, p. 177. Downs makes the important point that this system, managed by a corps of women factory superintendents, functioned as one additional component of the rationalizing impulse of the war and interwar years.

28. Ibid., on the wartime activities of the superintendents, pp. I66-185, and pp. 233-275 on the interwar years; see also Fourcaut, Femmes à l'usine, pp. 200-207.

29. Stovall, "The Color Line".

30. I am indebted to Antoinette Burton for calling attention to these points.

31. Of course, these intersections occurred also in practice as Tyler Stovall demonstrates in "The Color Line". 
differently racialized bodies governed perceptions of productive work. ${ }^{32}$ According to a report on the use of colonial and foreign workers during the war, written by B. Nogaro and Lucien Weil (1926), productivity differed according to the "unequal value and different aptitudes of the diverse races [...]". ${ }^{33}$ The report found Moroccans, Kabyles and Berbers to be "sturdy" and "energetic", and suitable for industrial work (munitions), whereas Arabs were more appropriate for agricultural work. The Indochinese (who included Cambodians, Cochin-Chinese, Annamites, and Tonkinois) on the other hand, tended to be "soft and submissive" and made good unskilled workers for powder factories or agriculture. In thus feminizing the body of the colonial male subject, Nogaro and Weil illustrated how racialized difference altered the gendered characteristics of bodies. In addition to endowing Indochinese workers with the classically "feminine" characteristics of softness and submissiveness, the report considered that the Indochinese were especially suitable for work "requiring dexterity as opposed to physical for$\mathrm{ce}^{n}$ - the very characteristics most often claimed for work gendered female, and associated with beliefs about women's superior fine motor coordination and their "nimble fingers". "The Indochinese", it concluded, "[have] no more strength than women" ${ }^{34}$ Nogaro and Weil also observed physical differences among white Europeans: Greeks tended to be hardy and strong, but resisted working out of doors; Portuguese peasants, on the other hand, had considerable strength and made good agricultural workers. In contrast to the instability of gender markings of colonial workers, with respect to European workers, observers assumed both race and gender as stable, if not normative categories. ${ }^{35}$

\section{STUDYING GENDERED AND RACIALIZED BODIES BETWEEN THE WARS}

Quite apart from the specific experience of the war, the cultural meanings of gender and racialized difference entered the study of the body at work

32. See Stovall, "The Color Line", p. 747.

33. Nogaro and Weil, La main d'oeuvre étrangère, p. 26. There were approximately 30,ooo North African workers already in France prior to the war, most of whom worked as unskilled laborers in mining and industry (p. 5). In 1915, the Undersecretary of State for Artillery and Munitions in the Ministry of War hired several hundred Kabyle workers for artillery manufacture and the Minister of Agriculture hired several hundred for agricultural work in the region south of Paris. A more systematic mobilization of colonial labor began in 1916. On the differences in treatment of European and colonial labor, see Stovall, "Color-blind France?".

34. Stovall, "Color Blind France?", p. 48. Stovall observes that during the war, such supposed physical characteristics came to be viewed as a moral deficiency: laziness. Dexterity was the skill most often associated with women, usually because of cultural beliefs about women's superior fine-motor coordination and their "nimble fingers". See, for example, Downs, Manufacturing Inequality, pp. 83-84.

35. Nogaro and Weil, La main d'oeuvre étrangère, pp. 49-50, 54. 
independently of issues directly related to the war. Jean-Marie Lahy's critique of Taylor incorporated a gendered model of the industrial worker:

One cannot abstract the worker from the man who takes part in social activities in which he occupies a more clevated position than in the factory. Head of the family, he assumes all the moral responsibilities that the direction of a household and the education of children imply; as a citizen, he participates in political life among the most active individuals. ${ }^{36}$

Lahy deserves credit for recognizing that work science could not treat the body of the worker as abstracted from the worker's gender or social and political identities, but his assumptions about the social and political significance of gender could not be mistaken. Nonetheless, Lahy's research showed the capacity of work science to move beyond stereotypical views of the productivity of gendered bodies, with potentially positive effects for workers. During the course of a labor conflict where women protested against piece rates that were twenty-five to thirty-five per cent lower than men's hourly wages, the conservative leader of the male-dominated Typographers' Federation, Auguste Keufer, defended the ideal of the fermme au foyer and rejected women's appeals for the same hourly wage as men. When Lahy was asked to study the productivity of men and women workers to help resolve the dispute, he observed that women linotypists produced results "rarely ourdistanced by men" and deserved the same wage as men. As for objections about the insalubrity of the work, Lahy replied that, "where women shouldn't be working, men shouldn't work either", implying that the health of the bodies of both men and women deserved to be taken into account. ${ }^{37}$ But this was a relatively rare instance in which work science would abandon historical and cultural ideas about women's weakness or incapacity for work.

The work scientist Jules Amar, in studies published after the war, continued to leave unexamined centuries-old assumptions about the female body, despite the fact that women refused to disappear from industrial work and increased the ranks of public service workers after World War I. The second edition of his Le Moteur humain, published in 1923, reaffirmed ageold ideas about male and female difference, confusing physiology and gender. In studying the cranial capacities of French men's and women's brains, for instance Amar insisted that although he could discover no difference between men and women in the "quantity of energy produced" by their brains, he did see a difference in quality. "In the case of the woman, sensibility holds the first place; [...] In man on the contrary, abstract thought and reason come first. ${ }^{38}$ Amar's next logical step was to insist that such

36. Lahy, Le Systeme Taylor, p. ix.

37. Ribeill, "Les débuts de l'ergonomie en France", p. 24. See also William H. Schneider, "The Scientific Study of Labor in Interwar France", French Historical Studies, 17 (1991), p. 418.

38. Amar, Le Moteur humain, 2nd ed. (Paris, 1923), p. 43. 
characteristics produced the aptitudes that would allow employers to assess the fit between workers and jobs and should be used as a basis of professional aptitude testing. ${ }^{39}$ Amar's work on physiology consolidated gender as a category defining the white worker: the maleness or femaleness of white French workers was unambiguous. The meanings of gender when applied to racialized workers were much more complex, as his work on colonial labor demonstrated.

In his studies of the endurance and fatigue of North African men carrying weights while walking and climbing, Amar attempted to classify racialized difference, again introducing race as a category only applicable to colonial subjects..$^{40}$ He recruited his subjects from petty criminals housed in the Algerian prison of Biskra, reminding us of how male colonial subjects could be mobilized - not only as a reserve army of labor (or as a reserve army tout court), but in the service of European "science" as well. In North Africa he could find men presenting "the physical and moral temperament of beasts of burden [le tempérament physique et moral du boeuf]". ${ }^{4}$ Amar claimed that examination of the brain did not enable him to arrive at firm conclusions about racial difference between Europeans and non-Europeans. Although he claimed to have found that "the brain of the negro [...] is less massive and less dense [than that of the European]", he argued that there was no firm relationship between physiological characteristics and the laboring capacities of colonial male workers. ${ }^{42}$ At the same time, he concluded that:

[...] the Muslims and the Kabyles are superior to all the Arabs in respect of the amount of daily labor of which they are capable, and the rapidity of their movements. More nervously constituted, they instinctively tend to work rapidly, and it is difficult to moderate the swiftness of their [motions].

In industry and in the army, speed is a valuable factor, and presupposes a [...] neuro-muscular system which reacts without delay. The Berbers appeared to display the vivacious reaction of the French workmen, while the other Arabs displayed the slowness of our peasants without possessing their tenaciry. ${ }^{43}$

Although Amar's North African subjects allegedly showed no difference from white, French-born subjects when carrying burdens on a flat surface, Arabs proved to be less powerful than white Europeans or North African Berbers when it came to climbing. Kabyles were deemed especially wellsuited to industrial work and physical exertion - true beasts of burden. ${ }^{44}$ Although the essential element of difference for Amar lay in the differential

39. Ibid., p. 116.

40. On Amar's study of racialized bodies at work, see also Ribeill, "Les débuts de l'ergonomie en France", pp. 14-16 and Camiscioli, "Labor Power and the Racial Economy", pp. 4-6.

4I. Amar, Le Moteur bumain, p. $\mathrm{x}$.

42. Ibid., pp. 43-44.

43. Ibid., pp. 219-220. This observation also revealed how white French workers' characteristics were defined. I am grateful to James Cronin for pointing this out.

44. Ibid., p. 220. 
labor power of white European and non-European bodies of color, despite their common racialized "affinity" not even all white Europeans shared the same physical aptitudes for work. Amar distinguished Italian from French workers, arguing that Italians "lacked energy" and did not seem capable of "the continuity of effort which our modern industries require $[\ldots]^{\text {". }} .45$

This work also incorporated two important issues that preoccupied work science in the 1920s and 1930s in a world where the rationalization and regulation of the working body came to be seen as a solution to both the pervasive sense of cultural crisis and the palpable crisis of productivity in postwar France. One was the idea of selection - the application of work science to measure the worker's aptitudes in order to match the individual to the most appropriate job. Amar believed, along with nineteenth-century "solidarists", that scientific selection would create social harmony between capital and labor and avoid labor conflict. Work could then truly become a form of social integration and an instrument of social progress. These ideas received further attention after the war in the research of Henri Laugier, Henri Piéron, Edouard Toulouse, Julien Fontègne, and Jean-Marie Lahy, who worked in state-sponsored laboratories and institutes such as the Conservatoire des Arts et Métiers, the Henri Rousselle Hospital, the National Institute for Vocational Guidance, and research laboratories of the École des Hautes Etudes en Sciences Sociales. ${ }^{46}$ A second set of issues concerned social and industrial hygiene and particularly the improvement of occupational health and safety and the prevention of work accidents. ${ }^{47}$ It was perhaps not surprising that work science should receive the support of the state in the 1920 and 1930s, particularly since both French entrepreneurs and the

45. Amar, The Physiology of Industrial Organization, p. 204. See also Camiscioli, "Labor Power and the Racial Economy", p. 6. The only defect of the French laborer was that "his temperament is impulsiven. Amar believed French workers needed better vocational training and better hygiene at work. He also believed that well-trained French workers should travel to the colonies to train native craftsmen. "Moreover, it is the duty of the European worker to direct native labor which is naturally adapted to fatiguing kinds of work which would not tax the native's endurance as greatly as it would ours [...]" (p. 210) [emphasis is mine - LLF].

46. See Schneider, "The Scientific Study of Labor". On how the arguments of these men transcended solidaristic arguments for marrying the interests of labor and capital, see Cross, $A$ Quest for Time, Pp. 120-122. As Cross also points out, in Britain work scientists believed that the increased leisure that would result from a shorter, more efficient working day and higher productivity would allow Britain to "build an improved race [...]" (p. 120). This is a not atypical example of the looseness with which the notion of race was used to reflect both whiteness and nationality. On the vocational guidance applications of work science, see also Mary Louise Roberts, Civilization Without Sexes: Reconstructing Gender in Postwar France, 1917-1927 (Chicago, IL, 1994), pp. 183-196 and 206-211.

47. Much of the research of these laboratories was specifically directed towards the prevention of industrial accidents and focused on masculine jobs such as those of railway switchmen, tramway and bus drivers, welders, and mine workers. See, for instance, Lahy, La Sélection psychophysiologique des travailleurs: conducteurs de tramways et d'autobus (Paris, 1927) and articles in the review Travail humain founded by Lahy and Laugier in 1933. See also Schneider, "The Scientific Study of Labor". 
state became preoccupied with rationalizing and modernizing industry and state services. Because of the way in which work science and the study of fatigue had defined gender and racialized difference, these issues likewise had gender and racialized dimensions.

\section{RATIONALIZING THE TELEPHONE EXCHANGE}

In the interwar years, the French combined elements of both Taylorism and work science in applying rationalization to selection and the division of labor. Although most studies of rationalization have focused on industry, the application of the scientific organization of work to the gendered bodies of workers occurred in service sector work with equal intensity. Office, clerical and secretarial work saw the distillation and implementation of scientific management and work science in the $1920{ }^{4}{ }^{8}$ Operating under the assumption that "the organization of the office should be inspired by methods of industrial organization", a small number of French managers applied time and motion studies to evaluate the efficiency of office work, reorganize tasks, and replace skilled white male workers with young men and girls. In the accounting division of some offices, where men, long hired as accountants because of their alleged skill with numbers and fine penmanship, gave way to women typists, prized because of their "nimble fingers".

The modernization of the telephone service in this period also involved the application of work science and the scientific organization of labor to the rationalized workplace and illustrates the convergence of discourses about gendered and racialized bodies and workplace practices. ${ }^{49}$ The aggressive feminization of the telephone service in the 1880 os coincided with both a major economic depression and the dramatic expansion of the number of telephone customers. ${ }^{\circ}$ The new "dames employées" constituted a distinct

48. See Delphine Gardey, "Un Monde en Mutation. Les Employés de Bureau en France, I89o1930. Féminisation, Mécanisation, Rationalisation"; Thèse de Doctorat nouvelle régime. Université de Paris VII, 1995, pp. 824-833. See also Harry Braverman, Labor and Monopoly Capital: The Degradation of Work in the Twentieth Century (New York, 1974), pp. 306-326.

49. See "L'organisation méthodique du Travail et son Application aux Postes et Télégraphes", Annales des PTT, 8 (1923), pp. 835-976; "Le Téléphone en France et à l'Etranger. Progrès technique, organisation rationnelle", Annales des PTT, 8 (1923), PP. 565-598; "Administration industriellen, Annales des PTT, 2 (1917), PP. 356-386.

5o. This story of the feminization of the French postal and telephone service is well told by Susan Bachrach in Dames employées: The Feminization of Postal Work in Nineteenth Century France (New York, 1984), pp. 30-5o. See also Jeanne Bouvier, Histoire des dames employées dans les Postes, Télégraphes, et Téléphones (Paris, 1930); Dominique Bertinotti, "Carrières féminines et carrières masculines dans l'administration des postes et télégraphes à la fin du XIXe siècle", Annales. ESC, 3 (1985), pp. 625-640. The grade, "dame employée", actually included all women working in the postal, telegraph and telephone (PTT) service; Bachrach, Dames employées, p. 42. On differential wages, see Bachrach, Dames employées; Pierrette Pezerat and Danielle Poublan, "Femmes sans maris. Les employées des postes", in Arlette Farge et Christiane Klapisch-Zuber (eds), Madame ou Mademoiselle? Itinéraires de la solitude feminine, 18e-20e siècle (Paris, 1984), p. 123. 
division or grade of public-sector worker that was paid less than male operators and would not compete with men. The employment of white women operators as a distinct category moreover, illustrates how the postal and telephone service, Postes, Téléphones et Télégraphes (PTT), was already rationalized along gender and racialized lines from the very beginning. Rationalization and fragmentation of the "labor process" operated differently for men. Whereas women were hired as specialized workers from the very beginning, the postal administration was reluctant to force male labor to specialize in order to allow men to move from one job to another as need arose. As the civil service hierarchy grew more refined after World War I, men, too, became increasingly specialized.

Between the end of the nineteenth century and the turn of the twentieth century, the number of women operators soared, from 812 in 1891 to over 3,300 just after the turn of the century. After the war (192I), about 46,000 women worked in all services of the PTT, the vast majority as telephone operators; by 1936 the service employed over 56,000 women. ${ }^{51}$ The administration believed that women's distinctive physical attributes made them good operators, although as well shall see below, the same characteristics could subvert the efficient operation of the system. The rationalizating impulses of Taylorism and work science came together in the 1920 and I930s in the management of telephone operators in three ways: attention to the gendered and raced body in the selection of candidates; scientific studies of the working body; the regulation of physical space and surveillance; and concern about the health of the worker in the modern telephone exchange.

\section{SELECTING THE OPERATOR}

Selection of the telephone operator involved the construction of a new kind of public service worker whose class position was ambiguous. It was well known that state public sector work could be a means of upward social mobility. Although the young operator could be working-class, more often she came from the lower middle class, and she had to be armed with at least an elementary school certificate. Indeed, education ranked among the important criteria for selection and both before and after World War I, the administration (of the PTT) favored women candidates possessing teaching certificates. ${ }^{52}$ All candidates took a battery of tests that included writing,

51. Madeleine Vignes, Les téléphonistes des PTT (préface de Madeleine Rebérioux) (Paris, 1984), p. I2; Bachrach, Dames employees, p. 69. Figures on the interwar period are not disaggregated by service, see République française. Ministère du Travail, de l'Hygiène, de l'Assistance et de la Prévoyance sociale, Statistique générale de France. Résultats statistiques du Recensement générale de la Population (1921, 1926, 1936) (Paris, 1922, 1928, 1937). Women counted for 22.5 per cent of PTT workers in 1906, 30.3 per cent in 1926 and 32.8 per cent in 1936.

52. Bachrach, Dames employées, p. 51; Bertinotti, "Carrières féminines", p. 637. 
spelling, arithmetic, physical and political geography of France and the colonies, physics, and chemistry. They could also take an optional examination in English, German, Spanish or Italian. In addition, following a training period in telephone communication, successful candidates had to pass a practical test that included techniques of transmission and reception. The administration gave priority to women who were already employed in the postal service or who were the wives, widows, daughters, or sisters of former male employees who were either retired or deceased. ${ }^{33}$ Although there was no marriage bar, about half of the women entering postal work were single and tended to remain so over the course of their employment. ${ }^{54}$ Just after World War I, candidates had to be between seventeen and twenty-five years of age (except for widows or orphans of men who had been killed in the war or who had died as a result of war-related injuries, who could be as old as thirty); by 1930, the lower age limit had been raised to twenty-one years, presumably following the shift in the legal age of majority." But beyond these formal requirements, selection criteria focused on physical attributes that theoretically could be verified during the course of an obligatory medical examination, but most of which had been already presumed as cultural and racial characteristics of the female body.

Beyond the formal requirements for admission to the examinations that permitted entry into public service work, selection included the more fundamental, gender and race criteria that fixed on the voice and body of the worker as the sites of skill and qualification. The future telephone operator had to be "française" and therefore white, living as she did, in the "shadow of colonialism".56 "White" or "whiteness" did not appear as a formal category, even among those attentive to race, and it is unlikely that the administration of the PTT would have even thought of employing such a category between the world wars. Yet, her whiteness was already inscribed in her Frenchness, a term that by definition did not apply to colonial workers who would have been specifically identified as such. As a representative of the French state in her capacity as a public sector worker, she could by definition not be a colonial immigrant nor of uncertain accent, reminding us of how public sector work could serve as a privileged if not racialized

53. République française. Ministère des PTT, Bulletin mensuel des PTT Janvier I8go (Paris, 189o), pp. 315-316; Bulletin mensuel des PTT, is (1922), pp. 411-415.

54. See Pezerat et Poublan, "Femmes sans maris", pp. 129-130, who report that in 1921, fifty per cent of all female postal workers were widowed, divorced, or unmarried. Although this figure incorporated the effects of male mortality during the war, it was consistent with low marriage rates among women postal workers before the war. The vast majority of male workers, on the other hand, tended to be married.

55. Bulletin mensuel des PTT, 18 (1922), p. 4II; République française. Ministère des PTT, Bulletin officiel du Ministère des PTT, 17 (1930), p. 694.

56. The phrase is Rayna Rapp's, (personal communication to the author). On the requirements for admission to the competency examinations where these criteria were spelled out, see, for example, Bulletin mensuel des PTT, I8 (1922), pp. 411-4I5. 
enclave, and reminding us as well that race is also about cultural competence. ${ }^{57}$ Colonial women - especially North African Muslim women would not have passed the tests of cultural competence as the French administration had defined them, even if cultural constraints on work did not exist for them. The post-World-War-I reconfiguration of sexual politics in the African colonies that gave white French women a specific role as the bearers of white Frenchness contained within it an unmistakable subtext against which Frenchness had to be defined. Observers of colonial life called attention to the Muslim women's dissimulation in wearing the veil, suggesting that they were untrustworthy; others criticized Arab cultural practices as "debauchery" and remarked on the hygiene of colonial subjects, which failed to meet French standards. ${ }^{58}$ Even the male colonial workers who had been gendered female by work scientists were not admitted to the competitive entrance examination. The future operator was required to submit a certificate attesting to her good moral character [certificat constatant qu'elle est de bonne vie et moeurs] signed by the mayor or the police commissioner of her town of residence. Significantly enough, the administration did not require character references for male candidates. ${ }^{99}$ After World War I, residents of the provinces of Alsace and Lorraine could take the examination in either French or German, but if they were unable to take it in French, they could only hope to work in the departments of the Haut-Rhin, the Bas-Rhin and the Moselle. ${ }^{60}$ Thus, constructing the public service worker also incorporated the reaffirmation of a certain representation of Frenchness and a nationally, if not racially, marked femininity.

57. Cultural competence also incorporated "civility", and itself contributed to the construction of Frenchness within the public service. See Elias, The Civilizing Process.

58. See Alice Conklin, "Redefining 'Frenchness': France and West Africa", in Julia Clancy-Smith and Frances Gouda (eds), Domesticating the Empire: Race, Gender, and Family Life in French and Dutch Colonialism (Charlottesville, VA and London, 1998), pp. 76-83. Janet Horne places somewhat more emphasis on white French women's "civilizing" work among Muslim women in North Africa whose wearing of the veil was considered a form of dissimulation and whose hygiene was by implication not up to French standards; Horne, "In Pursuit of Greater France: Visions of Empire Among Musée Social Reformers, 1894-1931", ibid., pp. 37-41. A somewhat different picture was painted by Hubertine Auclert in her Femmes arabes en Algérie (1900). See Julia Clancy-Smith, "Islam, Gender, and Identities in the Making of French Algeria, I830-1962", in Clancy-Smith and Gouda, Domesticating the Empire, pp. 168-172.

59. This difference suggests that nineteenth-century suspicions of the woman worker and especially the single woman worker remained alive in the period after the Great War. On those nineteenth-century suspicions, see Scott, " "L'Ouvrière, mot impie, sordide', [...]" and "A Statistical Representation of Work", in Gender and the Politics of History (New York, 1988).

60. Thus, "race" was also complicated by regionality - an employee who spoke with a thick regional accent was not acceptable unless her pronunciation could be "corrected". Moreover, "Frenchness" was still a category that distinguished among and between French women of different social, regional, and educational - as well as racial - backgrounds. I am grateful to James Cronin for raising this point. See République française. Ministère des PTT, Bulletin mensuel des PTT, 18 (1922), p. 412; Bulletin officiel du Ministère des PTT, 17 (1930), p. 695. 


\section{SCIENCE STUDIES THE OPERATOR: THE BODY AS MACHINE}

As work science developed and influenced the thinking of state managers in the their goal to modernize and improve telephone communication, the body became a new focus of attention. Women's pleasant voices, their alleged inherent patience and politeness, self-control, even-temperedness, aimiability, and "malleable character"; all figured among the "qualities" that made women desireable as operators, much as these same characteristics had been used for decades to justify the employment of women in other contexts. ${ }^{6 r}$ But work scientists and vocational guidance experts Julien Fontègne and his collaborator, Emilio Solari also gave serious attention to women's physical aptitudes for the work. In their work, the cultural meanings of gendered bodies underpinned science and what passed for modernity, and those cultural meanings were also racialized. ${ }^{62}$

Unlike work scientist Jules Amar, who rarely left his laboratory, Fontègne and Solari studied their subjects in the workplace. They attempted to develop the specific criteria that would determine whether a young women had the requisite physical aptitudes to be an operator. They studied the operator's routinized, repetitive movements performed rapidly and precisely in response to lights flashing on a switchboard. As soon as a caller picked up the telephone at home, a light appeared. The operator put a pin [fiche] attached to a cord into the jack, flicked a switch or pressed a button into the speaking position and immediately said "je'coute" [I hear you]. She then attempted to secure the number by touching the end of another pin to the jack of the corresponding number and putting the switch into the listening position to ascertain if the number was free. If it was, she introduced the pin into the jack and flicked another switch to signal the caller that the number was free. Once the person being called picked up the phone, and the connection was made, the lights went out. At the end of the conversation, the lights corresponding to caller and receipient went on and the operator registered the call with another switch and removed the pins. The operator repeated these mechanical movements hundreds of times in the course of an hour - the operators who Fontègne and Solari studied placed

61. See also Michele Martin, "Hello Central": Gender Technology and Culture in the Formation of Telephone Systems. (Montréal, 1991), pp. 58-60; Bachrach, Dames employées. See also Julien Fontègne and Emilio Solari, "Le Travail de la Téléphoniste. Essai de psychologie professionnelle", Archives de psychologie, 17 (1918), p. 92.

62. See Fontègne and Solari, "Le Travail de la Téléphoniste". Roberts argues that in debates about vocational guidance, the French attempted to "reconcile the ongoing modernization of economic and social life with time-honored cultural traditions"; Roberts, Civilization Without Sexes, p. 187. I am not so sure there was that much reconciliation to be done in matters of gender. The points of departure for both modernization and "cultural tradition" were the same: both already incorporated cultural notions of gendered bodies. 
between 160 and 180 calls an hour; during busy periods they had to handle up to 350 calls an hour. ${ }^{63}$

From their examination of the work, Fontègne and Solari developed a list of physical and psychological aptitides of the ideal operator. She should be tall, with long arms and a supple and elastic upper body. She needed good eyesight and hearing, a strong back, clear respiratory passages, and a normal digestive apparatus. In addition, she needed a good auditory memory for numbers; she had to be capable of sustained attention and be ready to respond at any moment. As Fontègne and Solari noted, this activity was very different from that of the office worker "who could put off work from one day to the next". The telephone operator needed to be able to react instantly to a variety of simultaneous stimuli including differently colored flashing lights and the sounds of callers. A good operator had to be able to demonstrate great rapidity and precision of movement. In short, she needed good nerves - a quality that men did not possess and which made them less desireable as operators. ${ }^{64}$ So, whereas in many contexts women had been excluded from jobs because of their "nervous qualities", scientists now rejected "muscles" in favor of "nerves", and argued that women's physical difference from men - their allegedly greater nervousness, their ability to move rapidly and react quickly to external stimuli, their capacity to give sustained attention to work, qualified them for the job. The gendered body itself and the nerves in particular constituted the locus of aptitude. ${ }^{65}$ The characteristics that Fontègne et Solari described were ideally suited to the Taylorized environment of the telephone exchange.

\section{REGULATION AND CONTROL}

Work scientists' criteria for the ideal operator were incorporated into the medical testing of candidates and into the handbook issued to young

63. Fontègne et Solari, "Le Travail de la Téléphoniste", pp. 85-86 and 95.

64. Ibid., pp. 93-95. Work science was applied to telephone operators even more aggressively in the Netherlands. See Robert Korving and Gerard Hogesteeger, "Psychotechnik bei der PTT Niederlande", in Helmut Gold and Annette Koch (eds), Fräulein vom Amt (Munich, 1993), pp. 120-134. On male operators, see Bouvier, Histoire des dames employées, p. 179.

65. Good nerves, of course, were not enough; Amar judged the Muslim and Kabyle men he tested to have good neuromuscular systems and display a capacity for quick reactions to stimuli, but they were never considered for this kind of work in France. Nor is it clear that they performed public sector work in the colonies. The qualities that work scientists and the state believed made women especially fit to be telephone operators illustrated the instability of gendered categories of skill. The shift from muscles to nerves as the desirable female quality that made women good operators involved a reversal of the frequent criticism of women's presumed "nervous" qualities. Thus women's supposedly inherent "nervousness" that made male workers criticize women's inappropriateness for certain tasks in the defense industries during World War I, for example, enabled them to be effective operators in the eyes of the PTT. 
operators, the vade-Mecum de la téléphoniste. ${ }^{66}$ This guide, which instructed new operators in the basic techniques of the work, claimed that unless workers understood the reasons for each task, "unconscious Taylorism" would transform them into robots, deprived of thought and initiative. ${ }^{67}$ But the handbook was really designed to regulate and discipline workers. It appropriately reminded operators to instill confidence in and maintain the confidentiality of the customer and guided them in dealing with irate or impatient callers. In addition, it instructed them in the correct placement of the heavy apparatus of headsets and adjustments of the microphone, which had to be kept at a few centimeters from the mouth so as to alleviate unnecessary stretching and straining of the neck. ${ }^{68}$ The operator's dress was also important. Metallic necklaces, bracelets, or wristwatches were forbidden because of the possibility of accidents from electric shocks or their ability to inhibit movement.

The rationalized work of the operator involved the meshing of body and machine. She was literally linked to the switchboard by the headset. The left hand operated the keys or switches; the right hand the pins. Even the voice was regulated, especially its timbre: one shouldn't speak loudly; it was sufficient that the voice was clear and articulate. "The syllables must be rhythmically separated so that they can be easily heard. One must not force the voice, but seek to fill the microphone with its volume; [...] one must shape one's words into the microphone [...] Pronounce not a single extraneous word." The motions of the hands had to be supple and precise. All stray motions had to be avoided. ${ }^{69}$

The desire to build a modern and efficient communications network for greater productivity, in effect - brought with it more rigid organization of space and the body, accompanied by an even more precise definition of the operator's motions. ${ }^{70}$ Indeed, the modern telephone exchange proved to be a model of rational discipline and control. It consisted of an enormous, long room whose walls were covered with switchboards. Women sat in straight-backed chairs close to a horizontal board of buttons and switches (the "table") and had to reach up to fit the pins into the appropriate jacks on the board. But discipline and regulation involved more than the spatial rationalization of the body. It also involved intense competition between operators and supervision to keep track of performance as a way of facilitating promotion. ${ }^{71}$ Competition between operators became a vehicle of providing rapid and efficient service for customers. It was as if the white

66. E. Rougier, Le vade-Mecum de la téléphoniste (Paris, 1927).

67. Ibid., p. 7.

68. Ibid., pp. 10-II.

69. Ibid., pp. $12-13$ and 17.

70. Catherine Bertho, Histoire des télécommunications en France (Toulouse, 1984), p. 75.

71. See Vignes, Les téléphonistes des PTT, p. 23 and Dominique Bertinotti, Artisans d'bier et communications d'aujourd'bui, I850-I950 (Paris, 198I), p. I4. 
female body had been transformed into a human motor: a tool of modernization of the public service.

The system of supervision and notation established by the administration also encouraged competition. Stationed at regular intervals in the hall, women supervisors (one supervisor for every ten to twelve operators) oversaw the smooth operation of the system. Some walked up and down behind the operators armed with clipboard and stopwatch to check periodically on the number of calls operators put through, and kept records of errors, "grading" the women on their performance. Another group of supervisors randomly listened in on the operators, monitoring their calls for quality. Operators found themselves under constant pressure to speed up the placement of calls. Grades became the basis of promotion. Absences from one's post, even to go to the restroom, were frowned upon - an operator couldn't simply get up to leave; she had to raise her hand and wait for the supervisor to give her permission to vacate her post. Although the administration had women work in shifts during the course of the day (from 7 a.m. to noon and from noon to 7 p.m., with another shift from 7 p.m. to 9 p.m.) and established rooms where women could lie down and relax periodically for fifteen minutes every two hours, managers attempted to extract as much effective labor as possible from the body of the operator. Thus, women who worked a shift from $7 \mathrm{am}$ to noon had to return in the evening to put in another two hours from 7 p.m. to 9 pm. Women who took sick leave were obliged to put in extra hours (known as a "return", retour), upon returning to work, or lost the rest period. As Jeanne Bouvier, labor organizer for the CGT remarked in her study of the téléphonistes, "[they lost] one franc a day during [an] absence and invariably [saw] their grades drop, thereby interfering with [...] possibilities for promotion". ${ }^{72}$

Regulation also extended from the telephone exchange into the arena of private life. Marriage, housing, and leisure all fell within the purview of the postal and telephone service. Despite the absence of the marriage bar, women who wished to marry had to make a formal request, by furnishing the administration with information about the person whom they intended to marry. ${ }^{73}$ In order to house the large numbers of young women who came to Paris from the provinces but who could hardly afford Parisian rents, the

72. Bouvier, Histoire des dames employées, p. 182. Women did resist some of these practices, although the majority of the labor struggles were directed not at the constraints of rationalization and work discipline, but at pay scales, poor opportunities for advancement and the elimination of the dame employée as a separate category with assimilation of women into the categories reserved for men.

73. See République française. Ministère de Commerce, de l'Industrie et des Colonies, Bulletin mensuel de Ministère de Commerce, de l'Industrie et des Colonies, I (1890), p. 315. This requirement remained in effect through the 1930s. It was based on the principle of incompatibity of certain public services (operators could not obtain authorization to marry policemen or mayors or assistant mayors, for example) and operated as another element of regulation. See Bouvier, Histoire des dames employées, pp. 204-205. 
administration built dormitories complete with "company" restaurants, such as the Maison des dames on the rue de Lille, just behind the former Orsay railway station (now the Musée d'Orsay). These dormitories regulated the operator's off-work hours; they could also, by means of the restaurant, provide some control over the health of the worker. In addition, the administration provided artistic, musical and sports clubs designed "to combine grace with dexterity", in an attempt to fill the leisure time of the young worker with rational, self-improving activities. ${ }^{74}$

\section{"LA NEVROSE DE LA TÉLÉPHONISTE"}

Although the operator's work seemed to be a model of regulation and control of the human motor, the same physical aptitudes that scientists and employers believed made women especially well-suited for the job also proved to be a liability. The rationalization of the telephone exchange produced a new focus on the body of the worker - occupational illness. Doctors reported on the "nevrose de la téléphoniste", a catch-all term for the nervous exaustion and multiple auditory and psychological problems operators experienced. Operators sought medical help for electric shocks, acute ringing in the ears or facial neuralgia brought on by defective headsets; some presented symptoms of depression, irritability and personality disturbances verging on hysteria. One doctor reported that in the latter, "one finds that the suggestion that the patient return to work is met with cries, sobs, and convulsions". He observed that "women are naturally more exposed to this malady [la névrose des téléphonistes] than men". ${ }^{75}$ But he also argued that what disturbed the "fragile brains of the Parisienne" was defective headsets and overwork. All the frustration of customers fell upon the operator. His solution was to perfect the headsets and recruit only young women with perfect hearing and healthy nervous systems. ${ }^{76}$ Other doctors also noted nervousness and headaches, stomachaches, insomnia, and back pain, all of which contributed to this professional illness, "nervous fatiguen. Thus, the very qualities of the body that made women desirable workers - their "nerves" - in the rationalized telephone exchange threatened the very rationalization of the system. ${ }^{77}$

74. Rougier, Le vade-Mecum de la téléphoniste, p. 24. The focus of these activities as well as of the housing arrangements for operators was the single women who made up the majority of telephone operators. Telephone operators, along with other postal workers, were awarded paid maternity leave in 1911. See (anonymous) "La Poste au Féminin", Réference, 7 (1984), p. I7.

75. Dr Clapart (fils), Maladies et Accidents professionnels des téléphonistes à Paris (Paris, I9II), p. 12-17. This was very likely because of the fact that the vast majority of operators were women who worked on the busy daytime shifts.

76. Ibid., p. 19 .

77. This is probably why Alexander Millerand, Minister of Public Works and the PTT in 1910, had proposed creating a revolving recruitment of young operators who would be encouraged by a system of bonuses to leave the administration at age twenty-five and who, in any case could work no longer than age thirty-five. See "Le Nouveau recrutement des téléphonistes", L'Action, 23 


\section{ORGANIZED LABOR REACTS}

Labor's consent to the claims of work science shows how workers, if not always sympathetic to scientific management, saw promise in work science. Telephone operators' delegates to the 1922 Congress of the National Postal Workers' Union (the Syndicat national des Agents des PTT [CGT]) favored work scientists' and doctors' recommendations for aptitude testing. They called attention to the physical effort, the weight of the headset, mental exhaustion, and the large number of sick leaves taken by operators and proposed more careful screening of the body - a more serious medical examination that "would focus on the overall physical constitution [of the candidate] and included a scrupulous auscultation and examination of the respiratory passages [...] [to determine] the physical aptitudes for the work".$^{78}$ Delegates' insistance that good selection would permit employers to find the right person for the right job and thus benefit workers was echoed by the claim of other delegates that "[organizing] our working conditions in the most scientific and rational way" would allow workers to obtain "superior productivity with less effort". ${ }^{79}$ In 1925, the Syndicat national took up the issue of professional training for both men and women, this time both in response to the demands of telephone operators and in reaction to more general complaints about the poor quality of the telephone service. This time workers blamed the engineers of the PTT for the problems with the service and proposed using the research of Lahy, Fontègne, and Solari for guidance to end operators' overwork. This would allow the administration to introduce "more humanity in the length of rotations, breaks, and regulation". Lashing out at the "Taylor system", as "devoid of any humanitarian concern", workers condemned Taylorism as "coming from the cold brain of an engineer who is only concerned with the output of human material", and asked for the development of a psychotechical laboratory in the PTT Administration on the model of laboratories that had been developed in Germany, to investigate scientifically the problem of operators' fatigue. ${ }^{80}$ Thus, postal workers argued that work science could be an antidote to the worst abuses of Taylorism.

February 1910. The rationale was to replace an ageing corps of operators with fresh blood. Since they were considered "floating personnel" they could be easily let go, permitting the administration to save money or adopt new technologies without worrying about the seniority of public service workers. The project was never adopted. On the concern with "nervous fatigue", see Cross, $A$ Quest for Time, p. I13.

78. Syndicat national des Agents des PTT (CGT), TVe Congrès des Agents des PTT tenu à Paris les 19-22 auril 1922 (Limoges, 1922). See especially the intervention of Mme Stanko, delegate for the operators, pp. 130-132. On labor's reaction to Taylorism, see Cross, "Redefining Workers' Control", and A Quest for Time; Ribeill, "Les Organisations du Mouvement", pp. I27-I40; Fridenson, "Un tournant taylorien".

79. Ne Congrès des Agents des PTT, pp. 107, $\mathrm{i} 40$. See also discussions in this congress on specialization and the scientific organization of labor.

80. Syndicat national des Agents des Postes, Télégraphes et Téléphones (confédéré), VIième Congrès national tenu à Toulouse les 10-13 juin 1925 (Epernay, 1925), pp. 268-283. One delegate's 
However, employers (and in this case, the state) tended to be more interested in organizing and disciplining the female body at work than addressing the problem of fatigue in more than a perfunctory manner. In a detailed report published in 1958 on work and fatigue, that focused on the operators' "neurosis", the writer expressed astonishment at how little had changed since the findings of Fontègne and Solari early in the century on operators' nervous fatigue. ${ }^{8 \mathrm{r}}$ Yet, the comparatively little attention given to the problem was entirely consistent with the productivist, modernizing thrust of economic policies of the interwar period. As Georges Ribeill and others have noted, work science was expensive and time-consuming; the rational organization of labor according to Taylor's principles appeared to give better returns for a smaller investment. And these workers were, after all, only women.

\section{CONCLUSIONS}

Historians of the French working class have already begun to show how gender and gendered meanings of work and the worker constituted "class" in the nineteenth and twentieth centuries. ${ }^{82}$ But until very recently "race" has been an absent or problematic category in much working-class history of France, where the myth of republican inclusion may have obscured the workings of racial difference in shaping the meanings and cultural practices of class. ${ }^{83}$ Re-examining scientists', employers', and the state's attention to working bodies however, suggests that these groups used both gender and racialized difference in defining class. Beginning in the late nineteenth century Europeans could invoke science to measure and regulate the body of the worker in order to serve the logic of capitalist command. The purpose of work science was to provide scientific foundations for the division of labor, not to question the cultural foundations of divisions according to

suggestion that a solution to the problem of operators' fatigue would be to introduce men into the telephone exchanges was laughed off. On the German use of psychotechnics, see Horst Gundlach, "Psychotechnische Untersuchungen bei der Deutschen Reichspost", in Gold and Koch, Fräulein vom Amt.

81. Dr D.P. Begoin, Le Travail et la Fatigue. Le Névrose des Téléphonistes et des mécanographes, special number of La Raison, 20/2I (1958).

82. See, for example, the essays in Frader and Rose, Gender and Class in Modern Europe; and Downs, Manufacturing Inequality.

83. Tyler Stovall's excellent work, cited above, is an important exception. There has been much work, of course, on the subject of racism in post-World-War-II France. An abundant literature has examined immigration and the salience of cultural and ethnic difference in shaping working class identities in the interwar and post-World-War-II periods (see, for instance, Nancy Green, Ready-to-Wear, Ready-to-Work: A Century of Industry and Immigrants in Paris and New York (Durham, NC and London, 1997) especially pp. 188-218 and 251-279). However, most historical work on immigration does not address the category of race nor does it attempt to theorize the meanings of racial difference in France, particularly in relation to France's colonial empire. This work remains to be done. 
gender or racialized difference. Rather, with few exceptions, work science, in conjunction with scientific management, reproduced those divisions faithfully and reinscribed differences on the bodies of workers. ${ }^{84}$ In doing so they reinforced the meanings of race and gender with respect to white French workers, while their work threw into relief the instability of the meanings of gender in the case of workers of color. In either case, those cultural meanings of gender and race attached to the body helped shape the meanings of class, influenced the shopfloor practices of both managers and the state, and served the French state's firtation with modernity on the floor of the telephone exchange. ${ }^{85}$

84. Of course, those differences dictated the terms of "scientific" investigation itself.

85. See Roberts, Civilization Without Sexes, p. 210, who cites Marjorie Beale, that the French adopted "techniques of social management [...] in order to preserve what they saw as traditional social relarions and cultural traditions". 